\title{
Teaching Reform and Practice Based on the Integration of Necessary Abilities of Jobs, Skill Contest and Professional Qualification Certificate into Courses-- Taking Architectural Engineering Surveying as an Example
}

\author{
Miaomiao CUI ${ }^{1, \text { a }}, \mathrm{Na} \mathrm{LI}^{2, \mathrm{~b}}$,Xia ZHAO ${ }^{3, \mathrm{c}}$,Xiaolin $\mathrm{ZHANG}^{4, \mathrm{~d}}$,Xiaowen BIAN ${ }^{5, \mathrm{e}}$ \\ 1,2,3,4,5 Architectural Engineering Department, Binzhou Polytechnic, Binzhou 256600,China \\ aemail: yulinglong808203@163.com, bemail: 411245815 @qq.com, cemail: 443183538@qq.com, \\ demail: $276547610 @ q q . c o m,{ }^{\mathrm{e} e m a i l:} 179042508 @ q q . c o m$
}

Keywords: Integration of Necessary Abilities of Jobs, Skill Contest and Professional Qualification Certificate into Courses; Teaching Reform; Architectural Engineering Surveying; Project Orientation

\begin{abstract}
The integration of necessary abilities of jobs, skill contest and professional qualification certificate into courses is an advanced teaching mode to meet the development of higher vocational education and to train highly skilled and application-oriented professionals. Taking the course design and teaching of architectural engineering surveying as an example, job competencies, skills contest abilities and professional qualification requirements are integrated into classroom teaching, which refers to enterprise, industry standards and focuses on the training of students' professional skills and development abilities. Work situations were created based on the curriculum teaching platform .Digital teaching resources were developed and the teaching method of project orientation, task driven and process assessment was used.The good effect of teaching reform has been obtained with fully improving the quality of personnel training.
\end{abstract}

\section{Introduction}

The integration of necessary abilities of jobs, skill contest and professional qualification certificate into courses is a new trend of course construction and education reformation, a developing tendency of higher vocational education and an advanced teaching mode for cultivating high skill and high quality talents. Urban-construction joint council , construction guidance committee for construction engineering technique major and construction implementation group of professional curriculum system built by the school and enterprises together are set up to cooperate further with industry, enterprise and professional skill identification organization.The knowledge, skills and professional accomplishment required by the students for jobs are included in the talent training programme and integrated into the teaching of related professional courses on the basis of formulating curriculum standards. Teachers and students are encouraged to participate in various professional skills contests to promote teaching and learning ,and to realize the integration of courses and contests. Because of the integration the new curriculum system and teaching content fully agree with the necessary abilities of jobs[1][2][3].

\section{Course Design of Architectural Engineering Surveying Based on the Integration}

Architectural engineering surveying which plays a major supporting role in the training of vocational skills and qualities of students is a core-competence course of architectural engineering technology. And it also lays a good foundation for the students to obtain the professional qualification certificate of the second construction engineer and to engage in the secondary employment position, which plays an important role in the curriculum system of the major.The professional ability requirements of construction crew, quality worker and surveyor are determined though the professional research of School-enterprise joint council in construction enterprises and surveying and mapping companies. By instructing students to participate in skill contests at all 
levels, the teachers deeply analyze the national vocational skill standards, technical specifications and the enterprise post abilities required of students. Furthermore, on the basis of the analysis of the requirements of professional qualification for the job and the extraction of the relevant professional knowledge in combination with the examination outline, the specific requirements of "job, contest, certificate" are translated into the knowledge and skill targets of course learning. The paper summarizes the corresponding relation of job, skill contest, vocational qualification certificate and teaching targets of architectural engineering surveying as shown in Table 1 [3] [4].

Table 1 the corresponding relation of job, contest, certificate and course target

\begin{tabular}{|c|c|c|c|}
\hline Job & Skill Contest & $\begin{array}{c}\text { Professional } \\
\text { Qualification } \\
\text { Certificate }\end{array}$ & Course Target \\
\hline $\begin{array}{l}\text { construction } \\
\text { crew ; } \\
\text { quality } \\
\text { worker ; } \\
\text { surveyor }\end{array}$ & $\begin{array}{l}\text { 1."Unicom Wopai Cup" } \\
\text { Shandong university students' } \\
\text { science-echnology culture and art } \\
\text { festival(surveying skill contest);2. } \\
\text { "ZhengYuan Geomatics Cup" } \\
\text { Shandong vocational college } \\
\text { students’ surveying skill contest; } \\
\text { 3. Shandong vocational college } \\
\text { skill contest(surveying and } \\
\text { mapping);4. National Vocational } \\
\text { College Skill Contest (surveying } \\
\text { and mapping);5. Binzhou } \\
\text { vocational college skill } \\
\text { contest(engineering surveying ) }\end{array}$ & $\begin{array}{l}\text { construction } \\
\text { crew ; quality } \\
\text { worker; } \\
\text { engineering } \\
\text { surveyor }\end{array}$ & $\begin{array}{l}\text { 1.skilled in the operation of } \\
\text { measuring instruments and } \\
\text { equipments; } 2 \text {. carry on the } \\
\text { basic work of measurement; } \\
\text { 3.set out known elevation, angle } \\
\text { and distance; } 4 \text {. building } \\
\text { positioning and laying out; } 5 \text {. } \\
\text { make the corresponding } \\
\text { construction survey plan and } \\
\text { organize the construction; } 6 \text {. } \\
\text { carry on survey inspection of } \\
\text { engineering constructions } \\
\text { according to measurement } \\
\text { norms; } 7 \text {. make topographic } \\
\text { map and carry on building } \\
\text { deformation observation. }\end{array}$ \\
\hline
\end{tabular}

Therefore, according to the professional abilities of job, the standard and norm of skill contest, and the requirement of vocational qualification examination, 6 teaching projects and 25 tasks relying on the course teaching platform have been set up for architectural engineering surveying in the light of the actual work flow (survey and design phase-construction phase-operation and management stage). The knowledge and skills which should be mastered by students through the course learning are given on the basis of these typical work tasks'analysis. For example, the content design of the first and second teaching items is shown in Table 2. 
Table 2 the course design based on the integration of necessary abilities of jobs, skill contest and professional qualification certificate

\begin{tabular}{|c|c|c|c|c|}
\hline \multirow{2}{*}{$\begin{array}{l}\text { Construction } \\
\text { Process }\end{array}$} & \multirow{2}{*}{$\begin{array}{l}\text { Teaching } \\
\text { Project }\end{array}$} & \multirow{2}{*}{ Work Task } & \multicolumn{2}{|c|}{ Learning Target } \\
\hline & & & Knowledge Target & Capability Target \\
\hline \multirow{8}{*}{$\begin{array}{l}\text { survey and } \\
\text { design phase }\end{array}$} & & $\begin{array}{l}\text { 1.basic } \\
\text { knowledge of } \\
\text { surveying }\end{array}$ & $\begin{array}{l}\text { 1.tasks ,functions, datum } \\
\text {, basic work, }\end{array}$ & master the datum, basic \\
\hline & $\begin{array}{l}\text { 1.basic } \\
\text { knowledge }\end{array}$ & $\begin{array}{l}2 \text {.overview of } \\
\text { architectural } \\
\text { engineering } \\
\text { surveying }\end{array}$ & $\begin{array}{l}\text { principles of } \\
\text { surveying;2.measuring } \\
\text { coordinate system and } \\
\text { elevation system; } \\
\text { 3.determination } \\
\text { methods of ground } \\
\text { points }\end{array}$ & $\begin{array}{l}\text { and principle of } \\
\text { surveying; master the } \\
\text { methods of determining } \\
\text { the position of ground } \\
\text { points }\end{array}$ \\
\hline & \multirow{6}{*}{$\begin{array}{l}2 . \\
\text { surveying } \\
\text { instrument }\end{array}$} & $\begin{array}{l}\text { 3.development } \\
\text { of surveying } \\
\text { instruments }\end{array}$ & \multirow{6}{*}{$\begin{array}{l}\text { 1. the structure and } \\
\text { operational steps of the } \\
\text { level; the measuring } \\
\text { steps of the leveling and } \\
\text { the calculation method } \\
\text { of internal work; 2.the } \\
\text { structure and principle } \\
\text { of theodolite; the } \\
\text { theoretical knowledge } \\
\text { of angle measurement; } \\
\text { 3.operation methods of } \\
\text { total station and GPS }\end{array}$} & \multirow{6}{*}{$\begin{array}{l}\text { 1.use the level quickly } \\
\text { and accurately; 2.carry } \\
\text { out closed and } \\
\text { coincidental leveling } \\
\text { line survey; 3. set up } \\
\text { theodolite quickly and } \\
\text { accurately;4.proficient } \\
\text { in horizontal angle } \\
\text { measurement of the } \\
\text { observation method in } \\
\text { two directions; 5. set up } \\
\text { total station and } \\
\text { measure angle,distance } \\
\text { and coordinate correctly } \\
\text { and quickly;6. use GPS } \\
\text { for RTK measurements }\end{array}$} \\
\hline & & $\begin{array}{l}\text { 4. level and its } \\
\text { application }\end{array}$ & & \\
\hline & & $\begin{array}{l}\text { 5. theodolite } \\
\text { and its } \\
\text { application }\end{array}$ & & \\
\hline & & $\begin{array}{l}\text { 6. measuring- } \\
\text { distance } \\
\text { instrument and } \\
\text { its application }\end{array}$ & & \\
\hline & & $\begin{array}{l}\text { 7.total station } \\
\text { instrument and } \\
\text { its application }\end{array}$ & & \\
\hline & & 8.GPS & & \\
\hline
\end{tabular}

Based on the learning targets of the curriculum design, the professional teaching standard of higher vocational college, the engineering survey specification, the outline of constructor's examination and the professional skill appraisal requirement of surveying and mapping geographic information industry are incorporated in the teaching of architectural engineering surveying. Teaching,we actively develop digital teaching resources and adopt informational teaching means. And the whole process reflects the mutual integration of necessary abilities of jobs, skill contest and professional qualification certificate into courses.

\section{Teaching Practice of Architectural Engineering Surveying Based on the Integration}

The subtask"Horizontal Angle Measurement of Two Directions"of the typical work task"5. theodolite and its application" is given as an example to introduce the actual teaching process of the course. "Horizontal Angle Measurement of Two Directions" is the work task that is refined according to the requirements of the job ability of the construction crew, the quality worker and the 
surveyor, which is one of the competition events of surveying skill contest at all levels and the necessary examination content of construction crew and three-level engineering surveyor. Therefore, the job ability analysis ,examination requirements and technical requirements(shown in Table 3 ) for the horizontal angle measurement of three-level traverse surveying in the engineering surveying norm are integrated in the teaching.

Table 3 basic technical requirements for traverse surveying ( 2 "stage angle measuring instrument)

\begin{tabular}{|c|c|l|l|l|l|}
\hline Level & $\begin{array}{l}\text { Position } \\
\text { Number }\end{array}$ & $\begin{array}{l}\text { Difference of } \\
\text { Two Half } \\
\text { Obsevation } \\
\text { Sets (") }\end{array}$ & $\begin{array}{l}\text { Difference of } \\
\text { Three Readings for } \\
\text { Distance } \\
\text { Measurement } \\
(\mathrm{mm})\end{array}$ & $\begin{array}{l}\text { Error of } \\
\text { Closure in } \\
\text { Azimuth(") }\end{array}$ & $\begin{array}{l}\text { Relative } \\
\text { Closure of } \\
\text { Traverse } \\
\text { Surveying }\end{array}$ \\
\hline three & 1 & 24 & 5 & $24 \sqrt{\mathrm{n}}$ & $\leq 1 / 5000$ \\
\hline
\end{tabular}

Note: $\mathrm{n}$ is the number of stations in Table 3 .

Based on the integration,knowledge,ability and quality target of "Horizontal Angle Measurement of Two Directions " are given as shown in Fig.1. Teaching priorities include the operation of angle measuring instrument (total station) and the measuring step of horizontal angle. The difficulties are the method of filling out the record form and the evaluation of measurement's accuracy. The core is to measure the horizontal angle safely and normatively.

Integration of necessary abilities of jobs, skill contest and professional qualification certificate into courses

\begin{tabular}{|c|c|c|}
\hline $\begin{array}{l}\text { Knowledge Target } \\
\text { the method of horizontal angle } \\
\text { measurement; the method and steps of } \\
\text { "Horizontal Angle Measurement of } \\
\text { Two Directions "; the method of filling } \\
\text { out the record form and the evaluation } \\
\text { of measurement's accuracy }\end{array}$ & $\begin{array}{l}\quad \text { Ability Target } \\
\text { carry on horizontal } \\
\text { angle measurement } \\
\text { expertly; fill out the } \\
\text { record form and carry on } \\
\text { the evaluation of } \\
\text { measurement's accuracy }\end{array}$ & $\begin{array}{l}\quad \text { Quality Target } \\
\text { cultivate the quality of } \\
\text { team cooperation and } \\
\text { rigorous work; establish } \\
\text { the occupational emotion } \\
\text { of " safety first and } \\
\text { prevention first " }\end{array}$ \\
\hline
\end{tabular}

Fig.1 teaching targets of "Horizontal Angle Measurement of Two Directions "

\section{The teaching process is as follows:}

1.Creating the work situation in combination with the curriculum teaching platform

The axes of the building has been set out at the construction site of no.2 teaching building. Axes'location needs to be checked,which includes two checking tasks: angle check and distance check. When checking the angle, we need to check the horizontal angle between the two adjacent axes.

2. Issuing the work task

According to technical requirements for the horizontal angle measurement of three-level traverse surveying, the horizontal angle between the two adjacent axes of the building is measured and checked with 2 " total station .

For example, take $\mathrm{O}$ as the occupied station and $\mathrm{A}, \mathrm{B}$ as the target points,measure the horizontal angle $\beta$ ( $\angle \mathrm{AOB})$ between the building axis OA and OB by the "Horizontal Angle Measurement of Two Directions ", fill out the record form earnestly and give the check result on the precision standard.

3.Task-driven,explaining priorities and difficulties,training exercises,examination and evaluation. 
The course examination and evaluation is transformed from the final skill examination into the mode that includes class process test,final skill examination,skill competition evaluation and professional qualification certificate score. Students are encouraged to actively participate in the skill contests, strive to obtain relevant professional qualification certificates and make the professional knowledge standardized, practical.

\section{Effectiveness of the Course Teaching Reform and Its Prospects}

The integration of necessary abilities of jobs, skill contest and professional qualification certificate into courses has greatly improved the quality of professional talents in architectural engineering technology. The passing rate of workers in construction projects in Shandong Province has reached over $90 \%$, while some students have obtained vocational qualification certificates for three-level engineering surveyors. Since 2014, we have won the second prize in Provincial Vocational College Skills Competition held by the Department of Education of Shandong Province (Surveying) for consecutive 4 years and also many awards in measurement competitions organized by industry and enterprises. Our Measurement Association has grown up to a provincial-level excellent society, and graduates are now in short supply as their knowledge, skills and professional quality are highly rated by employers. In the future, we will continue to follow the reference of "Opinions on Deepening the Teaching Reform of Vocational Education to Improve the Quality of Personnel Training in an All-round Way" (Measures for the Administration of Higher Vocational Education (Specialty) Majors in Colleges and Universities, Department of Vocational and Adult Education, Ministry of Education[2015] No. 6), and also the requirements of Standards (GJT2502011) in the occupational standards of the construction industry. Teaching reform of integrating necessary abilities of jobs, skill contests and professional qualification certificates into courses is going to keep on, to comprehensively improve the professional quality of students[5].

\section{Acknowledgements :}

Research on the innovation of modern apprenticeship training mode for construction majors in higher vocational colleges (ZC15074)

\section{References}

[1] Teaching Reform and Practice of Integrating Necessary Abilities of Jobs, Skill Contest and Professional Qualification Certificate, Maoying Li, Qingjun Zeng. Vocational Technology and Education, 2015(11), 36, 16-19.

[2] Study of the Teaching Mode "Matches of Necessary Abilities of Jobs, Skill Contest and Professional Qualification Certificate " in Vocational Education, Xiaosen Luo. Journal of Fujian Institute of Education, 2015(12), 95-97.

[3] Study of the Teaching Reform "Integration of Necessary Abilities of Jobs, Skill Contest and Professional Qualification Certificate "-Taking the Food Nutrition and Testing of Jiangsu Agriculture and Forestry Vocational College as Example, Yanli Han, Jun Jia, Zheng Cao, et al. Education and Teaching Forum,2016(16), 274-275.

[4] Analysis of Teaching Mode "Necessary Abilities of Jobs, Skill Contest and Professional Qualification Certificate ": Taking "Financial Regulations and Accounting Professional Ethics" Course as Example, Xuefei Fan, Times Finance, 2016(633), 246-247.

[5] Opinions on Deepening the Teaching Reform of Vocational Education and Enhancing the Quality of Personnel Training in an All-round Way, Measures for the Administration of Higher Vocational Education (Specialty) Majors in Colleges and Universities, Department of Vocational and Adult Education, Ministry of Education [2015] No. 6. 